\title{
In-depth proteomic analysis of boar spermatozoa through shotgun and gel-based methods
}

\author{
Jean M. Feugang ${ }^{1 *} \mathbb{D}$, Shengfa F. Liao ${ }^{1}$, Scott T. Willard ${ }^{1,2}$ and Peter L. Ryan ${ }^{1,3}$
}

\begin{abstract}
Background: Mature spermatozoa contain numerous epididymal and seminal plasma proteins, which full identification through high-throughput technologies may allow for a better understanding of the sperm biology. Therefore, we conducted a global proteomic analysis of boar spermatozoa through shotgun and gel-based methodologies.

Results: The total proteins were extracted from mature spermatozoa and subjecsted to proteome analyses. Functional analyses of gene ontology representations and pathway enrichments were conducted on the shotgun dataset, followed by immunology and gene expression validations. Shotgun and gel-based approaches allowed the detection of 2728 proteins and 2123 spots, respectively. Approximately 38\% and 59\% of total proteins were respectively fully and partially annotated, and 3\% were unknown. Gene ontology analysis indicated high proportions of proteins associated with intracellular and cytoplasm localizations, protein and nucleic acid binding, hydrolase and transferase activities, and cellular, metabolic, and regulation of biological processes. Proteins associated with phosphorylation processes and mitochondrial membranes, nucleic acid binding, and phosphate and phosphorous metabolics represented $77 \%$ of the dataset. Pathways associated with oxidative phosphorylation, citrate cycle, and extra-cellular matrix-receptor interaction were significantly enriched. Protein complex, intracellular organelle, cytoskeletal parts, fertilization and reproduction, and gap junction pathway were significantly enriched within the top 116 highly abundant proteins. Nine randomly selected protein candidates were confirmed with gel-based identification, immunofluorescence detection, and mRNA expression.
\end{abstract}

Conclusions: This study offers an in-depth proteomic mapping of mature boar spermatozoa that will enable comparative and discovery research for the improvement of male fertility.

Keywords: Fertility, Fertilization, Semen, Spermadhesins, Swine

\section{Background}

Spermatozoa are haploid cells produced in the testis with a specific shape allowing them to carry and deliver paternal materials to the oocyte. Their biology has a multifaceted array of genetic, proteomic and metabolic differences, which unpredictable interactions with one another could influence the sperm function and consequently, male fertility. Numerous studies have focused on both liquid and solid phases of semen ejaculates to investigate the multifactorial causes of male subfertility or infertility [1-4]. With regard to spermatozoa, various methods are being used to shed light on every aspect of

\footnotetext{
* Correspondence: jn181@ads.msstate.edu

'Department of Animal and Dairy Sciences, Mississippi State University,

Mississippi State, MS 39762, USA

Full list of author information is available at the end of the article
}

their structure and functionality. Motility and motion kinematics of spermatozoa are routinely assessed with computerized systems for objective, highly accurate and repeatable evaluations [5-7], while viability parameters such as the integrity of the plasma, acrosome, and mitochondrial membranes are evaluated with vital fluorescent dyes $[8,9]$. Still, these critical assessments do not always translate into a consistent prediction of semen quality and fertility.

Unpredictable interactions of spermatozoa with secretions found in the male reproductive tract make their biology more complex. Indeed, spermatozoa are released within the seminiferous tubules upon their production and maintain continuous interactions with surrounding secretions of the genital tract (testes and epididymis) throughout their longitudinal migration within the 
epididymis lumen and accessory sex glands (prostate, cowper's gland and seminal vesicles). These proteinbased interactions contribute to shaping the sperm structure and influence their fertility [10-14]. The quantity and quality of these proteins may vary significantly with the physiological and health status of the male, and only a global investigation of spermatozoa's total proteins and their interactions can help understand and address problems associated with sperm manipulation and fertility [15].

This past decade has been marked by the rapid development of high-throughput technologies allowing fast discoveries of the wealth of sperm molecules (i.e., RNA transcripts and proteins). The use of high-throughput techniques for either profiling or comparative studies of spermatozoa has been successful in various species such as the bull $[4,16-19]$, mice, rat $[20,21]$, men $[15,22]$, and the worm Caenorhabditis elegans [23]. Various proteomic platforms exist and a wide range of protein numbers have been detected in spermatozoa across and within species. To date, the best estimate figures are found to be between 2500 and 3000 proteins [15, 24-26] using either shotgun or gel-based analytical methodologies.

Each methodology has advantages and disadvantages [24-27]. The shotgun methodology is a bottom-up approach requiring an initial digestion of the crude protein extract into peptides to allow the identification of a greater number of proteins, but information concerning their likely post-translational modifications are lost. In contrast, the gel-based approach can afford a means for discovery, but several critical variables such as the protein extraction methods, the relative amount of proteins within extracts, the magnitude of the $\mathrm{pH}$ gradient in the first dimension, the molecular weight range in the second dimension, the means by which proteins will be stained, and repeatability remain and limit the amount of detectable proteins in samples [24, 28, 29].

So far, the rationale of selecting one technical approach over another has been driven by the objective of the study [30], and both methodologies have been used independently or in combination in many species for either profiling or discovery studies $[25,26]$. Contrary to many other species [22, 31], gel-based proteomics have been the preferred methods in boar spermatozoa studies [32-34]. In spite of the usefulness of the gel-based approach, only limited numbers of proteins have been identified and the full profiling of boar spermatozoa is necessary for an in-depth comprehension of their biology to speed biomarker discoveries in an effort to improve fertility outcomes in swine. A similar approach has been recently undertaken to boost the proteome of boar seminal plasma from less than $100[10,35]$, to several hundred (536) identified proteins [36].
Here, we employed both shotgun (nanoLC-MS/MS) and gel-based (2-DE) proteomic approaches, followed by functional bioinformatics (functional annotations, enrichment, and biological pathways) analyses to provide a panoramic overview of the proteome of mature boar spermatozoa. Validations were conducted with in situ immunofluorescence, westernblotting, and mRNA gene expression. This study confirms the power of the shotgun proteomic at generating large amounts of proteins compared to the gel-based method, while providing the first and most comprehensive proteome of mature boar spermatozoa. Additionally, the bioinformatic analyses indicate the likely importance of oxidative phosphorylation, citrate (TCA) cycle, and ECM-receptor interaction and gap junction pathways on sperm function. Generated dataset will be useful to better understand the biology of boar spermatozoa that is needed to further improve fertility diagnosis and prognosis of males and develop appropriate strategies for efficient post-collection handling of semen, particularly in swine.

\section{Methods}

\section{Semen collection and sperm purification}

Twenty-four semen ejaculates (3 per boar) of eight fertile Landrace boars (Table 1 ) of approximately 1.5 years old were purchased (International Boar Semen; Eldora, IA). Each semen ejaculate was extended with the Beltsville Thawing Solution (BTS: Minitube of America MOFA; Verona, WI) at the boar stud facilities and overnight-shipped to our laboratory, in three different occasions (one ejaculate/shipping). Twenty-four extended semen doses of sperm motility averaging $85 \pm 2.7 \%$ (mean \pm sem) at collection, were used in this study. Sperm motility were evaluated upon reception in our laboratory $(75 \pm 3.8 \%)$ and spermatozoa were purified through a discontinuous percoll gradient as previously reported [37]. After several washes with cold phosphate buffered-saline (PBS), sperm samples devoid of contamination (e.g. extender components and somatic cells such as leukocytes and testicular cells) were stored in aliquots of $100 \times 10^{6}$ spermatozoa per ejaculate and per boar at $-80{ }^{\circ} \mathrm{C}$. Samples were arranged for proteomics (three different ejaculate aliquots per boar; Additional file 1: Figure S1), immunodetection (immunofluorescence and westernblotting), and gene expression (RT-PCR) analyses.

Table 1 Boar reproductive characteristics

\begin{tabular}{ll}
\hline Expected Progeny Difference (EPD) class & Values (mean \pm sem) \\
\hline Number of offspring Born Alive (NBA) & $12.9 \pm 1.1$ \\
Total Litter weight (LWT; pound) & $184.2 \pm 4.2$ \\
Days at 250 pounds (D/250) & $151.5 \pm 0.5$ \\
Sow Productivity Index (SPI) & $110.5 \pm 4.4$ \\
\hline
\end{tabular}




\section{Shotgun proteomic}

For each boar $(n=8)$, spermatozoa of three different ejaculates were pooled $\left(3 \times 100 \times 10^{6}\right.$ spermatozoa $)$ and eight independent pools were used for analyses at the Institute for Genomics, Biocomputing and Biotechnology, Mississippi State University.

\section{Sample cleanup method}

Total protein of each boar $\left(3 \times 100 \times 10^{6}=300 \times 10^{6}\right.$ spermatozoa/boar) was extracted using the complete radioimmunoprecipitation assay (RIPA; Thermo Fisher Scientific Inc., Waltham, MA) buffer [38] and quantified (Bradford assay kit). Isolated protein samples were digested with trypsin and resulting peptide soup were desalted using a peptide macrotrap (TR1/25108/52; Michrom BioResources, Auburn, CA). After removal of the digestion buffer ( $2 \%$ and $90 \%$ acetonitrile, $0.1 \%$ formic acid), samples were cleaned using a strong cation exchange (SCX) trap (Michrom TR1/25108/53) to remove any detergents or other polymers that can interfere with MS/MS analysis. After further cleaning procedures through the SCX trap, the dried matrix of salt crystals and peptides were resuspended in $20 \mu \mathrm{l}$ of $5 \%$ acetonitrile, $0.1 \%$ formic acid and transferred to a low retention autosampler vial for deconvolution via reverse phase, high-pressure liquid chromatography.

\section{Nanospray LC/MS method}

Each sample was loaded on a BioBasic $\mathrm{C} 18$ reversed phase column (Thermo 72,105-100,266) and flushed for $20 \mathrm{~min}$ with $5 \%$ acetonitrile $(\mathrm{ACN}), 0.1 \%$ formic acid to remove salts. Peptide separation was achieved using a Thermo Surveyor MS pump with a 655-min nano-HPLC method consisting of a gradient from $5 \% \mathrm{ACN}$ to $50 \% \mathrm{ACN}$ in $620 \mathrm{~min}$, followed by a $20 \mathrm{~min}$ wash with $95 \% \mathrm{ACN}$ and equilibration with $5 \% \mathrm{ACN}$ for 15 min (all solvents contained $0.1 \%$ formic acid as a proton source). Ionization of peptides was achieved via nanospray ionization using a Thermo Finnigan nanospray source type I operated at $1.85 \mathrm{kV}$ with $8 \mu \mathrm{m}$ internal diameter silica tips (New Objective FS360-75-8-N-20-C12). High voltage was applied using a t-connector with a gold electrode in contact with the HPLC solvent. A Thermo LCQ DECA XP Plus ion trap mass spectrometer was used to collect data over the 655 min duration of each HPLC run. Precursor mass scans were performed using repetitive MS scans, each immediately followed by three MS/MS scans of the three most intense MS peaks. Dynamic exclusion was enabled with duration of $2 \mathrm{~min}$ and repeat counts. Once a mass is measured twice, it is added to a list to be excluded from further analysis for a predetermined amount of time, which was $2 \mathrm{~min}$. This allowed the MS to collect data on different masses, while in the meantime, the mass will have eluted from the column. Dynamic exclusion allows for a more efficient and deeper sample coverage [39].

\section{Gel-based proteomic}

For each boar $(n=8)$, spermatozoa of 3 different ejaculates were pooled $\left(300 \times 10^{6}\right.$ spermatozoa) and 8 independent pools were submitted to Applied Biomics (Hayward, CA, USA) for analyses.

\section{Protein lysate preparation}

Total protein was extracted as described above $\left(300 \times 10^{6}\right.$ spermatozoa/boar) and resuspended with $200 \mu \mathrm{l} 2 \mathrm{D}$ lysis buffer [ $2 \mathrm{M}$ thiourea, $7 \mathrm{M}$ urea, $4 \%$ ( $w / v)$ CHAPS, $30 \mathrm{mM}$ Tris- $\mathrm{HCl}$ ( $\mathrm{pH}$ 8.8)]. Samples were sonicated, centrifuged at high speed, and supernatants were collected, and protein quantified and normalized to $5 \mathrm{mg} / \mathrm{ml}$ with the 2-D cell lysis buffer.

\section{Isoelectric focusing (IEF) and SDS-PAGE}

Protein preparations $(5 \mathrm{mg} / \mathrm{ml})$ were mixed with $2 \times$ concentrated 2-D Sample buffer [8 M urea, 4\% CHAPS, $20 \mathrm{mg} / \mathrm{ml}$ dithiothreitol or DTT, $2 \%$ pharmalytes and trace amount of bromophenol blue - 0.002\% (w/v) -], followed by an addition of $100 \mu \mathrm{l}$ Destreak solution and Rehydration buffer (7 M urea, $2 \mathrm{M}$ thiourea, 4\% CHAPS, $20 \mathrm{mg} / \mathrm{ml} \mathrm{DTT}, 1 \%$ pharmalytes and trace amount of bromophenol blue). Protein samples $(350 \mu \mathrm{l}=300 \mu \mathrm{g})$ were placed into a strip holder for protein loading in $18 \mathrm{~cm}$ IPG strips. The IEF was run as recommended by Amersham BioSciences, under dark at $20{ }^{\circ} \mathrm{C}$. Thereafter, IPG strips (pH 3-10) were incubated in a fresh made equilibration buffer 1 (50 mM Tris- $\mathrm{HCl}, \mathrm{pH} 8.8$, containing $6 \mathrm{M}$ urea, $30 \%$ glycerol, $2 \% \mathrm{SDS}$, trace amount of bromophenol blue and $10 \mathrm{mg} / \mathrm{ml} \mathrm{DTT}$ ) for $15 \mathrm{~min}$ with slow shaking. The strips were transferred to a freshly made equilibration buffer $2(50 \mathrm{mM}$ Tris- $\mathrm{HCl}, \mathrm{pH} 8.8$, containing $6 \mathrm{M}$ urea, 30\% glycerol, 2\% SDS, trace amount of bromophenol blue and $45 \mathrm{mg} / \mathrm{ml}$ Iodoacetamide) and incubated $10 \mathrm{~min}$ with slow shaking. Afterwards, the IPG strips were rinsed once in the SDS-gel running buffer and placed onto 12\% SDS-Gel electrophorese gels and sealed with $0.5 \%(w / v)$ agarose solution (in SDS-gel running buffer). The SDS-gels were run at $15^{\circ} \mathrm{C}$ and stopped until the front dye runs out of the gels.

All gels $(n=8)$ were fixed and stained with the Bio-Safe colloidal Coomassie Blue G-250 solution (Bio-Rad Laboratories, Hercules, CA).

\section{Image scan and data analysis}

Image scans were carried out immediately following the SDS-PAGE using Typhoon TRIO (GE Healthcare) following the manufacture's protocol. Scanned images were analyzed by Image QuantTL software (GE-Healthcare) and subjected to in-gel analysis and cross-gel analysis 
using DeCyder software version 6.5 (GE-Healthcare). Spots with either protein score or total Ion (C.I. \%) greater than 95 were considered significant and protein candidates were randomly selected for spot picking.

\section{Spot picking, in-gel trypsin digestion, and MS}

The spots of interest were picked up by Ettan Spot Picker (GE Healthcare) based on the in-gel analysis and spot picking design by DeCyder software. Gel spots were washed few times and digested in-gel with modified porcine trypsin protease (Trypsin Gold; Promega, Madison, WI). Digested tryptic peptides were desalted by Zip-tip C18 (Millipore) and eluted from the Zip-tip with $0.5 \mu \mathrm{l}$ of matrix solution ( $\alpha$-cyano-4-hydroxycinnamic acid, $5 \mathrm{mg} / \mathrm{ml}$ in $50 \%$ acetonitrile, $0.1 \%$ trifluoroacetic acid, $25 \mathrm{mM}$ ammonium bicarbonate) and spotted on the MALDI plate. Mass spectrometer (MALDI-TOF) and TOF/TOF (tandem MS/MS) were performed (5800 mass spectrometer; AB Sciex), and MALDI-TOF mass spectra were acquired in reflectron positive ion mode, averaging 2000 laser shots per spectrum. TOF/TOF tandem MS fragmentation spectra were acquired for each sample, averaging 2000 laser shots per fragmentation spectrum on each of the 10 most abundant ions present in each sample (excluding trypsin autolytic peptides and other known background ions).

\section{Protein identification and bioinformatics}

Database searches were performed using the SEQUEST algorithm in Bioworks 3.3 [40] and GPS Explorer 3.5 equipped with search engine (Matrix science) to search the Sus scrofa databases (NCBI-nr and ENSEMBL) for resulting peptide masses and matching peptide spectra. Proteins identified with shotgun were functionally annotated (Gene ontology or GO, Enrichment, and KEGG pathway) using online tools of Agbase (www.agbase.msstate.edu; [41]) and DAVID (Database for Annotation, Visualization and Integrated Discovery; DAVID Bioinformatics Resources 6.7; https://david.ncifcrf.gov/; [42]).

\section{Immunodetection of selected proteins Immunofluorescence for flow cytometry and microscopy} Immediately after sperm purification, aliquots of purified spermatozoa were fixed with $4 \%$ paraformaldehyde and submitted for immunofluorescence detection using standard protocol, as previously reported [43]. Briefly, suspended and fixed spermatozoa were successively permeabilized in PBS, containing 1\% triton-X100 (30 min), blocked in PBS containing 0.1\% Teween-20 and 0.5\% BSA (30 min), incubated overnight at $4{ }^{\circ} \mathrm{C}$ with commercial primary antibodies (Santa Cruz Biotechnology, Inc., Santa Clara, CA) diluted $100 \times$ with PBS, and finally incubated 60 min with FITC-conjugated secondary antibody (1/200 dilution). Between steps, samples were washed twice by centrifugation (800×g - $5 \mathrm{~min})$ and immunolabeled spermatozoa were submitted for flow cytometry evaluation (excitation of $488 \mathrm{~nm}$ ). Sperm cells incubated without any antibodies or only the secondary antibody served as negative controls to set up the flow cytometer (FACSCalibur; Becton Dickinson; Franklin Lakes, NJ). Sperm cells were excited with a 488-nm laser source and the FITC and the Propidium iodide (PI) dyes were detected with the FL-1 $(530 / 30 \mathrm{~nm})$ and FL-2 (585/42 nm), respectively. A total of 10,000 events was evaluated for data acquisition. In parallel, aliquots of immunolabeled spermatozoa were smeared and mounted onto histology slides with DAPI containing medium. Slides were visualized under a Laser Scanning Confocal Microscope 710 (Zeiss) with a plan-apochromat $63 \times / 1.40$ Oil DIC M27 objective and images were analyzed with the ZEN 2012 SP1 (black edition) software.

\section{Westernblotting}

Total protein was extracted from three different ejaculates per boar $\left(300 \times 10^{6}\right.$ spermatozoa) using the complete RIPA lysis buffer. After protein quantification, equal amounts of extracted proteins per each boar were pooled according to the ejaculate ( $n=3$ pools) and total of $30 \mu \mathrm{g} /$ pool was loaded onto wells of SDS-PAGE (4-12.5\% NuPAGE) gels for resolution at room temperature. In-gel proteins were transferred onto PVDF membranes and the immunoblotting procedure was performed according to the anti-rabbit WesternBreeze $^{\mathrm{Tx}}$ Chromogenic Detection kits (Thermo Fisher Scientific Inc.). Membranes were incubated $60 \mathrm{~min}$ with selected primary antibodies (1/500 dilution).

In both immunological techniques, primary antibodies raised against human aquaporin 1 (AQP-1) and 7 (AQP-7), sodium/glucose co-transporter 5 (GLUT-5), plasminogen (PLG), protamine-1 (PRM-1), and thioredoxin reductase 1 (TRXR-1) purchased at Santa Cruz Biotechnology, Inc. were used. Otherwise indicated, all procedures took place at room temperature.

\section{Reverse transcription-polymerase chain reaction (RT-PCR)}

Total RNA were extracted from boar sperm samples using the RNeasy Mini kit (Qiagen, Carlsbad, CA) as previously described [37], with an in-column DNase digestion. Isolated RNA was reverse-transcribed into the complementary DNA (cDNA; Quantitech RT kit, Qiagen) and $0.25 \mu \mathrm{g}$ of cDNA was used for polymerase chain reaction (PCR) with primers specifically designed to amplify water aquaporin (AQP-1, -5 , and -11), aquaglyceroporin (AQP-3, $-7,-9$, and -10 ) sodium/ glucose co-transporter (GLUT-3 and GLUT-5) and spermadhesins (SPMI, AWN, AQN-1, PSP-I, and PSP-II) transcripts (Table 2). Samples were amplified in a total of $25-\mu$ l reaction volume using SYBR Green kit (Qiagen) within the Rotor-gene Q Thermal Cycler (Qiagen). The PCR conditions consisted of a hot start $\left(95^{\circ} \mathrm{C}-5 \mathrm{~min}\right)$, 
Table 2 Primer characteristics

\begin{tabular}{|c|c|c|c|}
\hline $\begin{array}{l}\text { Gene } \\
\text { names }\end{array}$ & $\begin{array}{l}\text { NCBI } \\
\text { Accession \# }\end{array}$ & $\begin{array}{l}\text { Primer } \\
\text { sequences }\left(5^{\prime} \rightarrow 3^{\prime}\right)\end{array}$ & $\begin{array}{l}\text { Produ } \\
\text { size }(b\end{array}$ \\
\hline \multicolumn{4}{|c|}{ Water aquaporins } \\
\hline AQP-1 & NM_214454 & $\begin{array}{l}\text { FP: CCGGCAACTCCCTTGGCCTG } \\
\text { RP: GGGTTAATGCCGCAGCCGGT }\end{array}$ & 220 \\
\hline AQP-5 & NM_001110424 & $\begin{array}{l}\text { FP: TGGGCTGGCACCTGGCAATG } \\
\text { RP: CGACTGCGGGGCCGAAAGAG }\end{array}$ & 266 \\
\hline AQP-11 & NM_001112682 & $\begin{array}{l}\text { FP: TGCGTGGGTGCCTTGTGGAG } \\
\text { RP: GTGCAGCAAAGCGCTGTGGAA }\end{array}$ & 150 \\
\hline \multicolumn{4}{|c|}{ Aquaglyceroporins } \\
\hline AQP-3 & NM_001110172 & $\begin{array}{l}\text { FP: TCGTGTGCGTGCTGGCCATT } \\
\text { RP: ACCGGCGATGGAACCCAGGA }\end{array}$ & 257 \\
\hline AQP-7 & NM_001113438 & $\begin{array}{l}\text { FP: AGTGACCGGTCCCACAGCCA } \\
\text { RP: CTGTGTGCCCCAGCCAGCAA }\end{array}$ & 295 \\
\hline AQP-9 & NM_001112684 & $\begin{array}{l}\text { FP: GGGCTGCAACCCTCTITGGCA } \\
\text { RP: TGGGCTGTAGGCCTCTGGGGA }\end{array}$ & 234 \\
\hline AQP-10 & NM_001128454 & $\begin{array}{l}\text { FP: GGGTCTGTGGCCCAGGCAGTA } \\
\text { RP: TGGCCAGGGAGAAGGCTGGA }\end{array}$ & 148 \\
\hline \multicolumn{4}{|c|}{ Spermadhesins } \\
\hline AQN-1 & NM_001025210 & $\begin{array}{l}\text { FP: CAGGCTGCTGAGATGAAGCTGGGC } \\
\text { RP: CGCAGGCGAGGTTGAGATACGG }\end{array}$ & 235 \\
\hline AWN & NM_213829 & $\begin{array}{l}\text { FP: GTCCTCAGAGACCCTCCTGGGAA } \\
\text { RP: GGAAGGGAGAGGCACGCTGG }\end{array}$ & 277 \\
\hline PSP-I & NM_213837 & $\begin{array}{l}\text { FP: GCGGTTCTTCAGGCATGACGGT } \\
\text { RP: GTGGCCAGGAGATGGCGCTC }\end{array}$ & 203 \\
\hline PSP-\|I & NM_213836 & $\begin{array}{l}\text { FP: ACTGCCATCCCCTGGGCCTT } \\
\text { RP: GCCGTAGACAAAAAGACAATCGCTG }\end{array}$ & 305 \\
\hline SPMI & NM_001031776 & $\begin{array}{l}\text { FP: TCCGAGACCAACGGGCAGGAC } \\
\text { RP: TGGCTCCTTGTGGGATGCCGT }\end{array}$ & 165 \\
\hline \multicolumn{4}{|c|}{ Glucose transporters } \\
\hline GLUT-3 & FJ_209733 & $\begin{array}{l}\text { FP: GGGGGCCTTGGCACTCTCA } \\
\text { RP: AAGCCCAAGAGCAGGGGCCA }\end{array}$ & 117 \\
\hline GLUT-5 & EU_012359 & $\begin{array}{l}\text { FP: TCGGCTCCCTCATGGTCGGC } \\
\text { RP: TGGGCGACTITGCTGCATCCC }\end{array}$ & 118 \\
\hline
\end{tabular}

40 cycles of amplification $\left(95{ }^{\circ} \mathrm{C}-15 \mathrm{~s}\right.$ and $60{ }^{\circ} \mathrm{C}-30 \mathrm{~s}$ ), and a final extension $\left(72{ }^{\circ} \mathrm{C}-5 \mathrm{~min}\right)$. Water was used as a template for negative control, while GAPDH was used as the housekeeping gene. All PCR products were subjected to electrophoresis on a 1.5\% agarose gel and product images were documented.

\section{Statistical analyses}

Sample collection was designed to minimize interejaculate and inter-individual variations, with spermatozoa harvested from three independent semen collections of eight fertile boars during spring (April and May). Proteomics were run on mixed aliquots of three ejaculates, per boar and for each boar. Only the shotgun proteome datasets providing higher number of proteins were used for statistical analyses according to Pendarvis et al. [44]. Peptide search results were filtered using a decoy based statistical method in which a probability of being a false positive match was assigned to each peptide. Proteins containing at least three peptides with a $P$ value (Benjamini-Hochberg correction) of 0.05 or less were retained as indicative of the confidence in protein identification and relative expression [45]. The enrichment of GO terms and KEGG pathways was identified through the Fischer's Exact Test with Multiple Testing Correction of FDR (Benjamini-Hochberg) used to calculate the probability that the association of proteins with given biological function or pathway was not due to random chance. Cutoffs were set for $P \leq 0.05$ and FDR $\leq 10 \%$.

\section{Results}

Total protein identification using shotgun

Nearly 90\% concordance was found amongst individual proteome dataset $(n=8)$. A total of 2728 unique and commonly shared proteins were identified with confidence among samples $(P \leq 0.05$; see Additional file 2 Total proteins). Total of 2406 detected proteins were annotated with NCBI-nr databases, corresponding to 781 (29\%) full and 1625 (59\%) partial annotations. Residual proteins showed 238 (9\%) annotations with ENSEMBL and $84(3 \%)$ that remained unknown (Fig. 1). With an arbitrary cut-off set at $P \leq 10^{-99}, 116$ proteins were delimited and considered highly abundant (Additional file 2 Abundant proteins). Of these abundant proteins, 61 were fully annotated (NCBI-nr) with many of them deriving from testes (i.e., fascin-3 and epididymal spermbinding protein 1) and sex glands (i.e., seminal plasma protein $\mathrm{pB} 1$, plasma sperm motility inhibitor, and angiotensin I converting enzyme). Number of abundant proteins appeared associated with sperm structure (i.e., protamine-1 or PRM-1, several tubulin family members, F-actin capping protein $\beta 1$ and 2 , and outer dense fiber protein or ODF1) and sperm-egg interactions (i.e., sperm acrosome membrane-associated protein 1 or SPACA1, sperm equatorial segment protein 1 or SPESP1, sperm adhesion molecule 1 or SPAM1, and spermadhesins (AWN, PSP-I/II, and AQN-3 or SPMI).

\section{Total protein identification using 2-DE}

A total of 2123 spots were shared among all boar samples $(n=8)$. Gel electrophoreses (Additional file 3: Figure S2) usually displaying likely bimodal protein distributions based upon their isoelectric points (from $\sim 5.0$ to 7.5 and from $\sim 8.0$ to 10 ) and their molecular weights (from $\sim 27$ to $80 \mathrm{kDa}$ and from $\sim 21-10 \mathrm{kDa}$ ). Eight randomly selected spots were identified through MS/MS as albumin (69 kDa - pH 5.8), PSP-I (12 kDa - pH 7.8), ODF1 (29 kDa - pH 8.4), acrosin inhibitor (11 kDa - pH 8.9), FActin capping protein subunit beta (31 kDa - $\mathrm{pH} 5.5$ ), AWN (17 kDa - pH 9.3), lactadherin precursor (48 kDa $\mathrm{pH}$ 6.3), and triosephosphate isomerase (27 kDa - $\mathrm{pH}$ 6.5). 


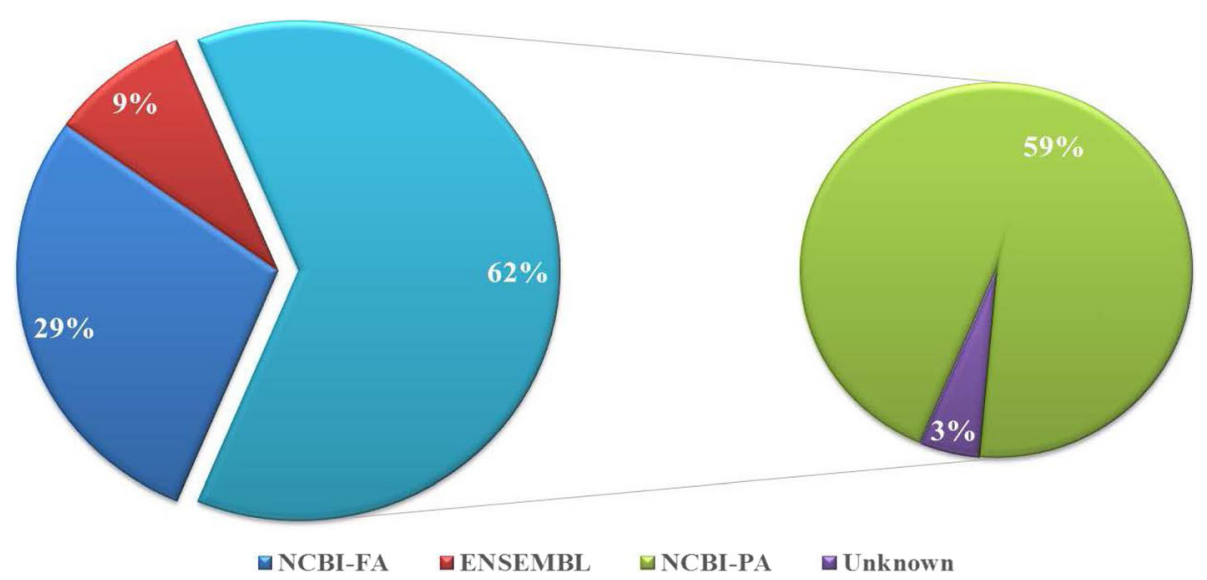

Fig. 1 Summary of the boar sperm proteome. Total of 2728 proteins were identified using shotgun method, with 781 fully (NCBI-FA) and 1625 partially (NCBI-PA) annotated through NCBI-nr, 238 annotated with ENSEMBL and 84 that remained unknowns

\section{Shotgun protein validation through immunotechniques} Aquaporins (AQP-1 and AQP-5), aquaglyceroporins (AQP-7), transferrin (TF), plasminogen (PLG), fibronectin1 (FN-1), and thioredoxin reductase 1 (TRXR-1) were immunodetected in sperm protein lysates (Fig. 2). With comparable protein loads into electrophoresis wells, signal bands of AQPs appeared weaker than that of TF, FN-1 and TRXR-1. These proteins together with GLUT-5 and PRM1 were targeted using in situ immunofluorescence, followed by confocal microscope imaging (Fig. 2); thus differential fluorescence intensities and localizations of proteins on spermatozoa were revealed. Representative indications of these differences are shown in Fig. 2, with TRXR-1 exhibiting a strong signal located in the apical (acrosome) region of the sperm head. In parallel, the PLG signal was mainly detected on the head and mid-piece regions of the spermatozoon. Additionally, flow cytometry revealed high proportions $(\approx 70-90 \%)$ of spermatozoa immunoreacting with anti-AQP-1, -AQP-7, -GLUT-5, -PLG, -PRM-1, and -TRXR-1 antibodies (Fig. 3a) and
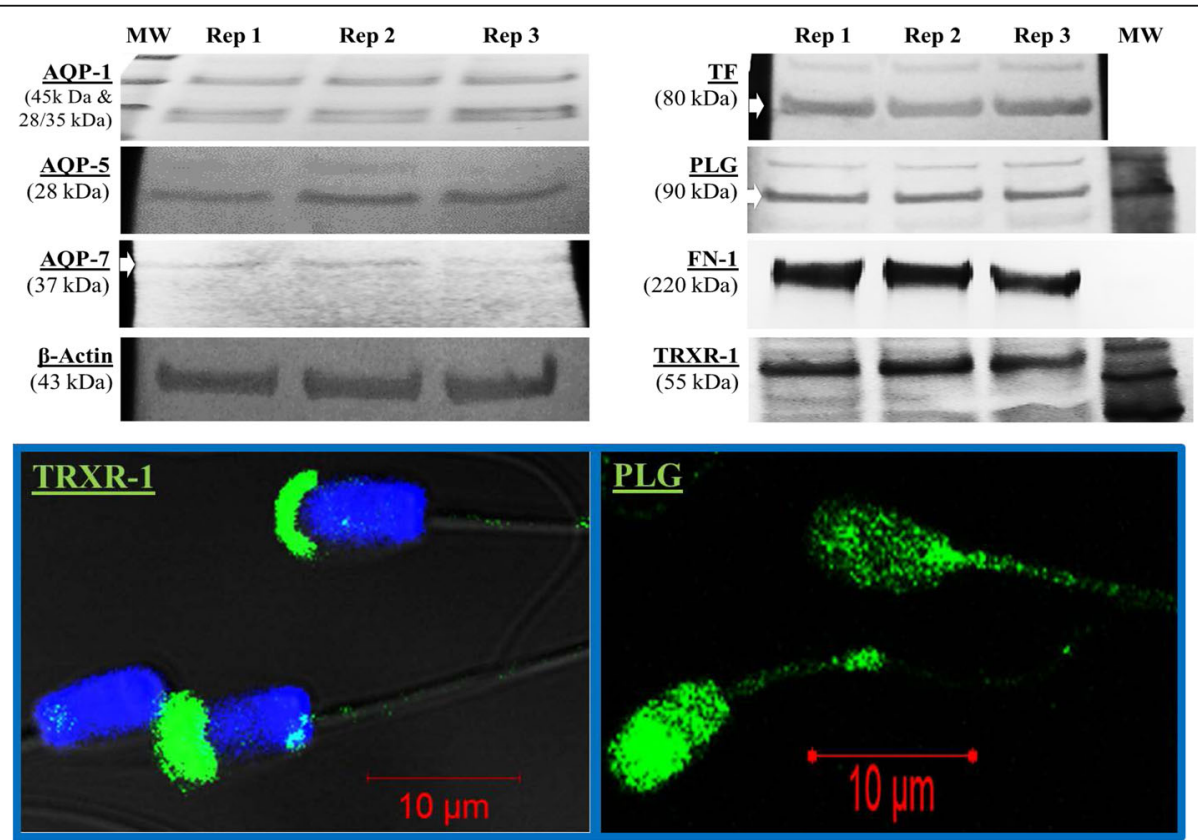

Fig. 2 Representative westernblots and in situ immunofluorescence of boar spermatozoa. Selected proteins were targeted with antibodies raised against human AQP-1 (45 kDa \& 28/35 kDa), AQP-5 (28 kDa), AQP-7 (37 kDa), ß-actin (43 kDa, the internal loading control), TF (80 kDa), PLG (90 kDa), FN-1 (220 kDa), TRXR-1 (55 kDa). In situ immunofluorescence micrographs of TRXT-1 and PLG are also shown. The FITC green fluorescence indicates the sub-apical (acrosome membrane) localization of TRXR-1 on the sperm head and the localization of PLG on the head and mid-piece of spermatozoon. Nuclei are counterstained in blue with DAPI 

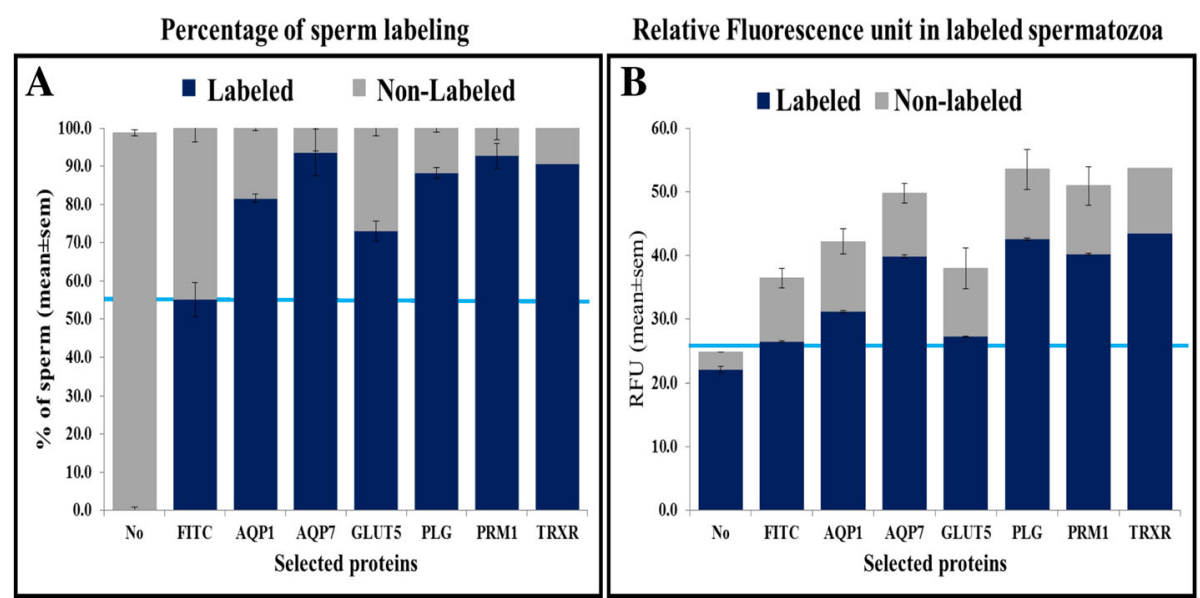

Fig. 3 Immunofluorescence quantification through flow cytometry. Columns labeled as "No" or "FITC" correspond to spermatozoa incubated without any antibodies or with FITC-conjugated secondary antibody only, respectively. a Percentage of immunopositive sperm cells and $\mathbf{b}$ Relative fluorescence intensity of labeled spermatozoa. Specific targeting is revealed above the blue line, suggesting for example for GLUT-5 detection, a lower proportion of cells being targeted (a) and which cells also show lowest or no specific detection of GLUT-5 (b)

fluorescence intensities significantly above the thresholds obtained with control spermatozoa incubated without antibodies (No) or with the FITC-conjugated secondary antibody only (Fig. 3b). The fluorescence intensities of sperm alone (non-stained or control; No) and sperm incubated with the secondary antibody only (FITC) can be seen in Fig. 3.

\section{Validation through gene expression}

Aquaporin (AQP-1, AQP-5, and AQP-11), aquaglyceroporins (AQP-3, AQP-7, AQP-9, and AQP-10), glucose transporters (GLUT-3 and GLUT-5), and spermadhesins (AQN-1, AWN1, PSP-I, PSP-II, SPMI) were targeted in this study. Data summarized in Fig. 4a indicate the detection of mRNA transcripts (Yes) in spermatozoa. Although similar amounts of cDNA were used for PCRs, the amplicon bands of each gene appeared at variable intensities as seen on the gel electrophoresis allowing for a relative classification, from weak $(+/-)$ to strong $(+++)$ for each gene target. In the current study, all spermadhesin family members and AQP-11 signal bands were the strongest, and Fig. $4 \mathrm{~b}$ shows a representative agarose gel electrophoresis of AQP-11 and SPMI amplification products. Fig. $4 \mathrm{a}$ also indicates the status of protein detection of each targeted gene in boar spermatozoa by either westernblotting (W) or immunofluorescence (IF).

\section{Functional analyses}

\section{Total proteins}

Analyses were performed on the shotgun dataset only and data with $\mathrm{P}$ (Benjamini-Hocheberg) $\leq 0.05$ and FDR $\leq 10 \%$ were retained for interpretations. A systematic search for compatible pig protein identifiers resulted in 2236 successful conversions (using GORetriever from Agbase), corresponding to $82 \%$ of the total sperm proteome being used for functional classification of all GO terms (Fig. 5). Detailed distributions of the biological functions are categorized per cellular compartmentalization (CC, with 2070 annotations), molecular function (MF, with 5659 annotations), and biological processes (BP, with 15,402 annotations).

For enrichment studies, the dataset with pig identifiers yielded only $39 \%$ conversions for DAVID analyses. However, the optimal conversion of $77 \%$ (2108 proteins) was reached by combining the residual unconverted pig identifiers with their human homologs, representing 67 Sus scrofa plus 2041 Homo sapiens proteins that were considered for analyses.

Totals of 67, 38, and $92 \mathrm{GO}$ terms were found significantly enriched $(P<0.05)$ within the $\mathrm{CC}, \mathrm{MF}$, and $\mathrm{BP}$ categories, of which 34,20 , and 24 had a FDR $\leq 10 \%$, respectively (Additional file 2 Total protein_FA). In comparison to GO term classifications by Agbase, terms associating mitochondria, extracellular matrix, and cytoskeleton in total proteins were significantly enriched was enriched $(1.4 \times-2.5 \times)$ in the CC category. Likewise, most GO terms (i.e., catabolic, transferase, and hydrolase activities and nucleic acid, protein binding and binding) highly classified in Agbase (Fig. 5) were significantly enriched through DAVID, in the MF category. Finally, GO terms associating response to chemical stimulus and biological, cellular, and metabolic processes in BP were significantly enriched $(\approx 1.1 \times-1.5 \times)$, and those associated with reproduction (i.e., sexual reproduction and reproduction) and oxygen consumption (i.e., oxidative phosphorylation, cellular respiration, and aerobic 


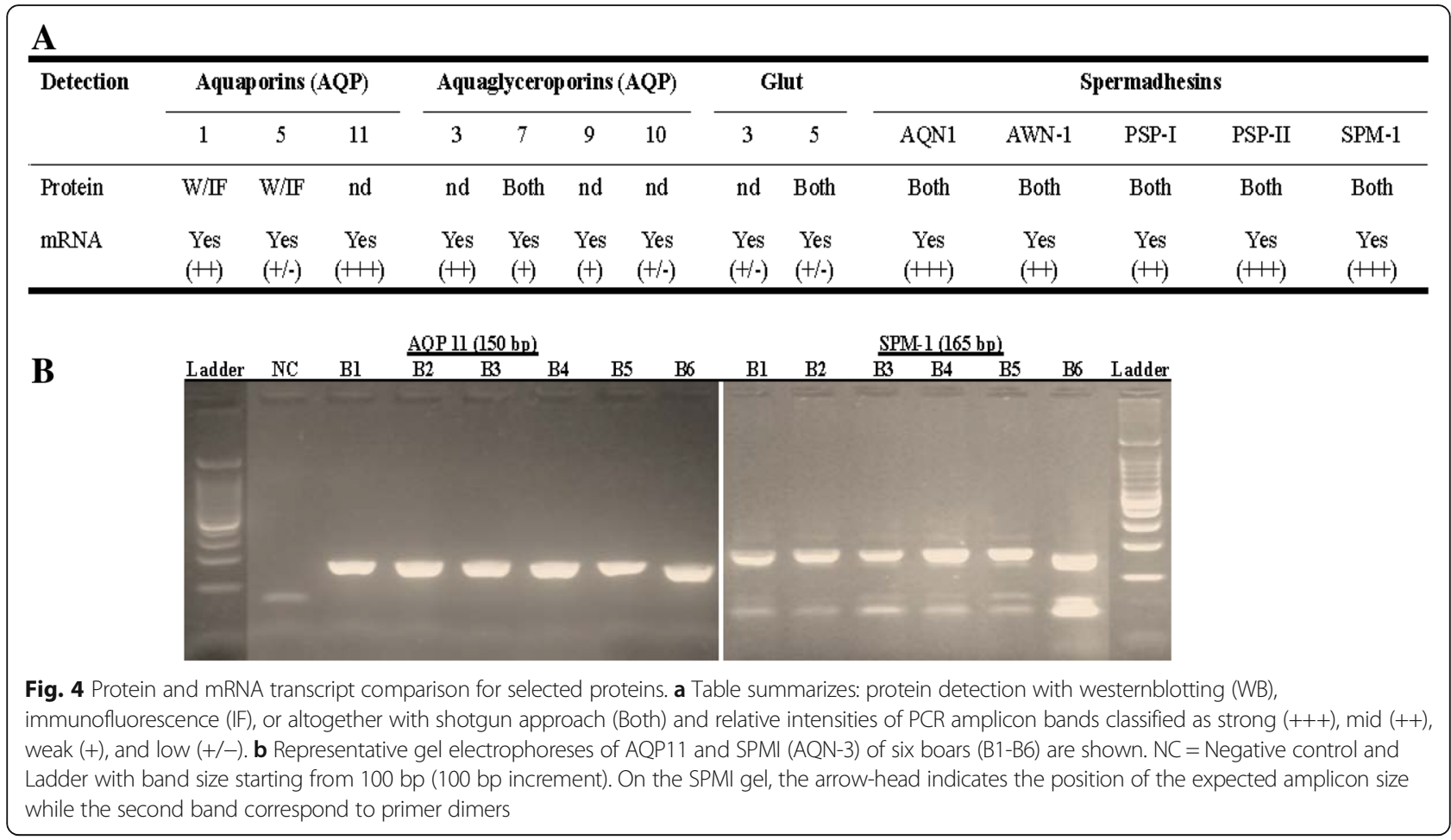

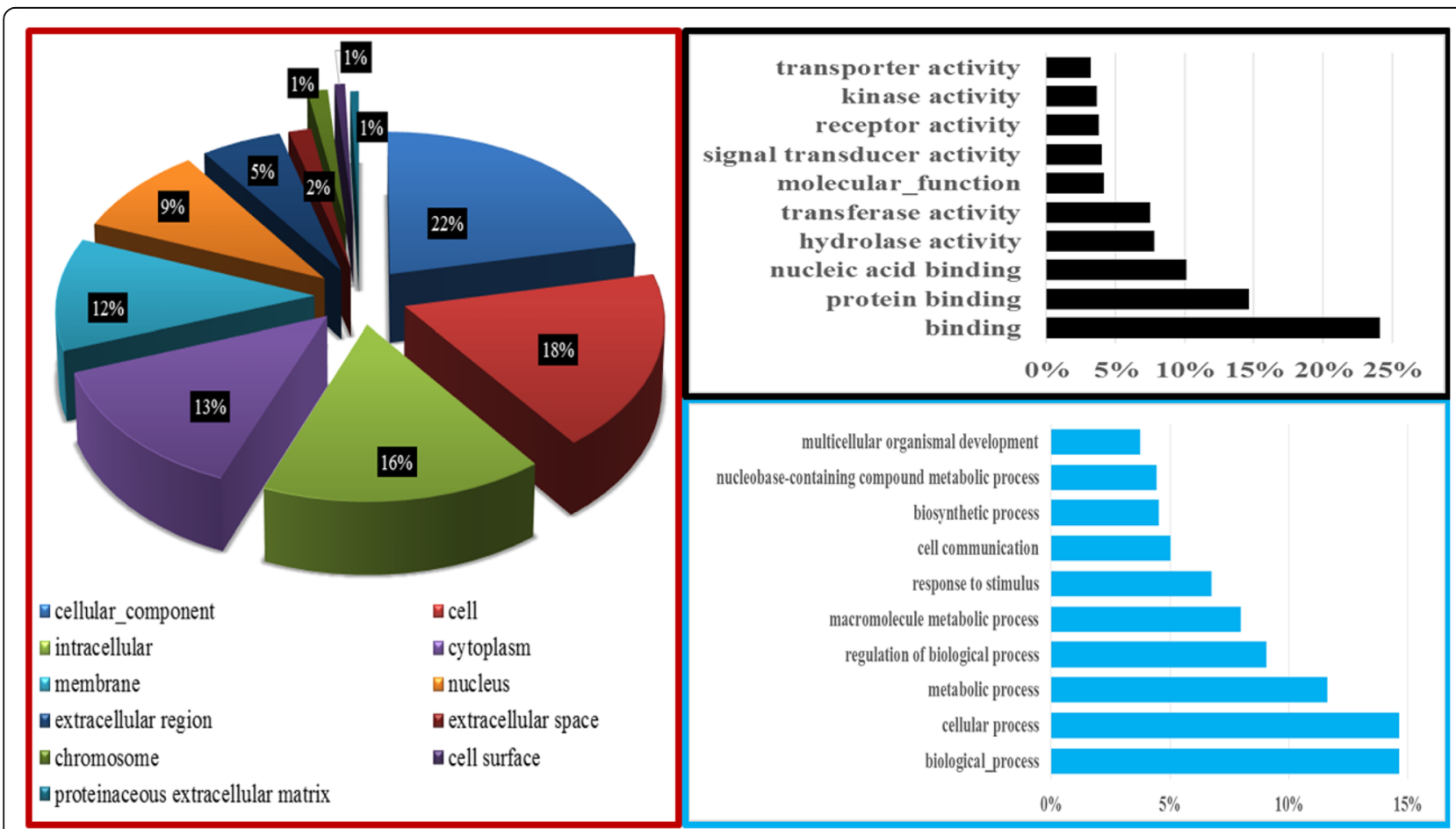

Fig. 5 Functional annotation of the boar sperm proteome. The distribution of total protein per gene ontology (GO) terms in the Cellular Component is shown in the red frame. The top $10 \mathrm{GO}$ terms in the Molecular Function and Biological Process categories are shown in the black and the blue frames, respectively 
respiration) appeared amongst the highly and significantly enriched $(>1.4 \times-3.6 \times)$ in the proteome dataset.

\section{Abundant proteins}

A total of $62 \%$ of proteins (71) were successfully converted to DAVID for analyses. Proteins associated with protein complex, cytoskeleton/cytoskeletal parts, and organelle GO terms were significantly expressed (3-9x) in CC category. Enrichments $(>12 \times, P<0.05)$ were found in favor of fertilization and reproduction GO terms in the BP category and proteins such as seminal plasma protein pB1, milk fat globule EGF factor 8 protein, epididymal sperm binding protein1, and sperm associated AWN protein, PSP-I/II, sperm adhesion molecule 1, zonadhesin, and zona pellucida binding protein are among the fertilization $\mathrm{GO}$ term (Additional file 2 Abundant protein_FA).

\section{Pathway analyses}

The KEGG pathway analysis of the total proteome revealed 21 hits, of which only oxidative phosphorylation, citrate cycle (TCA cycle), and ECM-receptor interaction pathways were significantly enriched, with respectively 35,13 , and 23 protein counts for each (Additional file 2 Total protein_FA). Enrichment folds varied from 2.0 to $3.2 \times$, with Benjamini $P$ values ranging from 0.004 to 0.032 and corresponding FDR from 0.05 to 1.09. Only the gap junction pathway was significantly overrepresented in the abundant protein list, with a fold enrichment of $11.8 \times$ and Benjamini $\mathrm{P}$ and FDR values of 0.0045 and 0.087 , respectively. This pathway comprised six proteins that included tubulin $\alpha 1 \mathrm{a}$, tubulin $\beta 1$, and tubulin $\alpha 3$ (Additional file 2 Abundant protein_FA).

\section{Discussion}

The full characterization of the global sperm proteome has the potential to provide new clues to better understand the genesis and maturation of spermatozoa and to lead to concrete improvement of reproduction outcomes. Here we used two common high-throughput techniques that have overlapping strengths and weaknesses [24, 27] for a comprehensive proteome profiling of boar spermatozoa to provide a unique dataset for further in-depth investigation and improvement of postcollection boar semen handling.

The use of the shotgun technique in this study provides the largest pool of boar sperm proteome (2728 total proteins) that falls into the current range reported in spermatozoa ( 1000 to $\sim 4000)$ of various species such as cow, horse, human, mice, and rat $[25,26,46]$. The study confirms the power of the shotgun (LC-MS/MS) over the 2DE (2D-MS/MS) method to generating greater number of proteins. Nonetheless, our 2-DE method yielded more protein spots (2123) than the unique reported number (1577) in boar spermatozoa [47].

Proteomic investigations are continuously and consistently showing discrepancies in the numbers of detected proteins between shotgun and gel-based proteomics $[24,27]$. This situation can be caused by sample preparation procedures, cut-offs in data acquisition and processing, as well as other factors known to limit the capacity of the 2-DE gels. For example, the presence of abundant proteins on the 2-DE gel compete for space and mask or prevent the detection of neighboring protein spots, while low expressed or less represented protein spots, as seen here with proteins within the 27$80 \mathrm{kDa}$ range (Additional file 3: Figure S2), may not be considered for analyses. Nonetheless, the gel-based proteomic (e.g., 2D-DIGE-LC/2MS) remains the main technique used for comparative studies performed with boar spermatozoa [33, 47-49], while the speed of discovery could be accelerated by the shotgun approach providing a panoramic proteome profile to allow for more complete comparative studies.

With $97 \%$ total protein being partially annotated, the current dataset provides a vast reservoir of proteins for further investigation and characterization of boar spermatozoa. Still, the shotgun proteomic is a bottomup holistic approach that needs further validation of detected proteins. Both immunotechniques and gene expression led to some conflicting findings, particularly with the immunodetection of proteins that are not found in the generated proteome dataset (e.g., PRM-1, AQP-1, and AQP-5) or already reported elsewhere by other authors. For example, previous studies have detected the epididymis secretory glutathione peroxidase or GPX5 [50] and AQP-11 [51] in their small-scale studies using westernblotting in pig spermatozoa. These two proteins are not present in our dataset, where conflicting findings may be due to the stringency of peptide number cut-off for the calling of proteins. In the present study, reported proteins are from peaks of at least three peptides that were shared among the MS/ MS runs of all individual samples $(n=8)$. It is therefore, likely that many proteins may have been filtered out in the current study, resulting in fewer observations as suggested in a previous report [27]. Furthermore, the gene expression study confirmed the presence of selected RNA transcripts in spermatozoa, including those of proteins not found in our study (e.g., AQP-1 and AQP-5). In sum, these findings highlight one of the disadvantages or limits of the shotgun proteomics, mainly for biomarker discovery $[51,52]$.

On the other hand, many known proteins such as spermadhesins and triosephosphate isomerase that are already reported in the literature were found in the current dataset $[47,53]$. Therefore, with $29 \%$ (791) of 
the total protein being fully annotated, the current dataset constitutes an important platform for future annotation updates that may lead to even greater numbers of proteins that will likely provide new research opportunities to enhance our comprehension of the biology of boar spermatozoa.

Meanwhile, the investigation of highly abundant proteins has the potential to boost the knowledge needed to make further progress in assisted reproduction. Numbers of these proteins are known to play crucial roles in 1) protecting spermatozoa from the acidic $\mathrm{pH}$ and antimicrobial immune responses of the vagina, 2) assisting spermatozoa during the cervical mucus transit $[54,55]$ or 3$)$ maintaining the function of spermatozoa until interactions with the oocyte [11]. Especially, spermadhesins have been reported as the major proteins of boar seminal plasma. Their expression has been detected in vesicular glands, epididymis and rete testis of boars while their secretions are found in the male genital tract and seminal plasma [11, 12, 52, 56, 57]. The presence of spermadhesins on sperm membrane and possible effects on sperm function, from motility to interaction with the oocyte, have been reported $[11,58,59]$. In addition to the current knowledge, our study brings further support to the small number of studies identifying the presence of heparin (AQN-1, AQN-3, and AWN-1) and non-heparin (PSP-I and PSP-II) spermadhesin mRNA transcripts in mature boar spermatozoa [52]. In the current dataset, $\mathrm{AQN}-3$ was identified as sperm motility inhibitor or SPMI, which is also known to bind plasma membrane of boar spermatozoa and act as sperm receptor of the oocyte zona pellucida protein [60]. More interestingly, three major proteins associated with acrosome vesicle (acrosin, zona pellucida binding protein, and acrosin binding protein) and having important roles during sperm-egg interactions [61-63] are among the abundant proteins. The roles of many abundant proteins on sperm function are yet to be determined, and the functional analysis is giving direction into which individual or group of proteins may deserve in-depth investigation of their roles.

We found that numerous proteins were overrepresented $(>1.1 \times-3.6 \times)$ in GO terms such as response to chemical stimulus and biological, cellular, and metabolic processes, oxidative phosphorylation, cellular respiration, an aerobic respiration, thus supporting a concerted effort of various pathways to regulate sperm function, especially motility. In this study, oxidative phosphorylation (vs. glycolysis) is coming up as the key or highly enriched metabolic pathway supplying the high demands for ATP, necessary to achieve progressive motility and more. However, experimental studies have shown the glycolytic pathway as the primary source of energy for sperm motility in many species, including pigs [64-67]. The likely contribution of oxidative phosphorylation to sperm motility may not be ruled out, as the detection of enzymes such as adenylate kinase and phosphoglycerate kinase that shuttle ATP away from the mitochondrion to the flagellum are suggesting the possible role of oxidative phosphorylation.

We also found that the gap junction pathway was highly and significantly represented within the in abundant proteins dataset. Gap junctions are intercellular channels relying on a family of protein membranes known as connexins. These molecules couple the cytoplasms of interacting cells to allow passage of ions and other small molecules [68]. Here, the gap junction enrichment together with the aforementioned "response to chemical stimulus" should not be a surprise given the variety of sperm interactions with their surroundings (i.e., fluids and uterine and oviduct cells). Indeed, interactions with chemical stimuli such as $\mathrm{K}^{+}$, $\mathrm{Na}^{+}, \mathrm{Ca}^{2+}$, and $\mathrm{pH}$ can leads to physiological events such as metabolic transport and signaling, capable to induce contractions in sperm assemblies resulting in motility. Studies have reported the capability of connexins 36 and 43 to anchor microtubules consisting of alpha and beta tubulin proteins dimerization [69]. Therefore, the abundance of tubulin proteins and their classification as part of the gap junction could be seen as a good indicator of their role in sperm motility.

Additionally, significant and high enrichments $(>12 \times)$ in favor of fertilization and reproduction GO terms were observed among abundant proteins; however, the full roles of associated proteins in sperm function remain to be determined [1].

\section{Practical implications}

Overall, the present study gives a panoramic list of proteins for further identification of biomarkers associated with various physiological traits of the male, which will be of interest for agricultural and translational purposes $[1,12]$. The current dataset confirms the presence of proteins (e.g., acrosin-binding protein, fibronectin 1, and triosephosphate isomerase) that have been proposed as potential predictors of semen freezability in previous studies [12, 32, 47, 49, 70]. Various glucose transporters, and aquaporin family members playing crucial roles during cell membrane permeability to water (aquaporins) and cryoprotectants (aquaglyceroporins) were detected. These findings contribute to the growing investigation of their roles in sperm function [51, 53, 71, 72], while the apparent weaker detection levels of aquaglyceroporins may be consequential to boar sperm freezability [73].

\section{Conclusions}

The proposed shotgun proteomics method is the first employed in boar spermatozoa and has allowed the 
identification of over 2 thousand proteins for a comprehensive bioinformatic analysis of their biological functions. Findings confirmed previous reports using different investigative methods and provide a large reservoir for further search of valuable biomarkers to improve assisted reproductive technology outcomes. Yet, the generated dataset is subjected to continuous update with future annotations to determine the functional significance of detected proteins for more insights into the male (in) fertility.

\section{Additional files}

\section{Additional file 1: Figure S1. Sperm preparation and proteomics.} (PDF $153 \mathrm{~kb}$ )

Additional file 2: Shotgun proteome data set analyses. File contains the total and abundant proteins, with associated functional analyses (Total protein_FA and abundant protein_FA). (XLSX $417 \mathrm{~kb}$ )

Additional file 3: Figure S2. Representative two-dimensional gel electrophoresis of the boar sperm proteome. (PDF $84 \mathrm{~kb}$ )

\section{Abbreviations}

2D-MS/MS: Two-Dimensional coupled with tandem Mass Spectrometry (MS/MS); ARTs: Assisted reproductive technologies; BP: Biological process; CC: Cellular component; ECM: Extracellular matrix; GO: Gene ontology; KEGG: Kyoto enclyclopedia of genes and genomes; MF: Molecular function; mRNA: Messenger ribonucleic acid; NCBI-nr: National Center for Biotechnology Information non-redundant; PBS: Phosphate-buffered solution SDS-PAGE: Sodium Dodecyl Sulfate -PolyAcrylamide Gel Electrophoresis; TCA: The Citric Acid or TriCarboxylic Acid cycle

\section{Acknowledgements}

We acknowledge Ken Pendarvis (University of Arizona) for proteomic analysis, Dr. Buza Teresia (Penn State University) and Dr. Fiona McCarthy (University of Arizona) for their assistance in proteomic analyses. We thank John Stokes and Wei Tan (College of Veterinary Medicine at Mississippi State University) for their assistance in flow cytometry analyses. We are grateful to the staff members of the Institute for Imaging and Analytical Technologies of Mississippi State University $\left(I^{2} \mathrm{AT}\right)$, especially Amanda Lawrence for their assistance during laser confocal microscope imaging. We thank Christy Steadman for her technical assistance.

\section{Funding}

This work was funded by the United States Department of Agriculture Agricultural Research Service (USDA-ARS grant \# 8-6402-3-018).

\section{Availability of data and materials}

All data generated or analysed during this study are included in this published article [and its supplementary information files].

\section{Authors' contributions}

JMF conceived and designed the study, assisted by STW and PLR; JMF executed all experiments, analyzed data, performed bioinformatics analyses, and wrote the manuscript; SFL assisted in the execution of experiments and data analyses. All authors contributed to data interpretation, manuscript development. All authors read and approved the final manuscript.

\section{Ethics approval}

This study involved the use of animal cell (spermatozoa) that were purchased at a commercial farm and no ethical approval was needed.

\section{Consent for publication}

Not applicable.

\section{Competing interests}

The authors declare that they have no competing interests.

\section{Publisher's Note}

Springer Nature remains neutral with regard to jurisdictional claims in published maps and institutional affiliations.

\section{Author details}

'Department of Animal and Dairy Sciences, Mississippi State University, Mississippi State, MS 39762, USA. 'Department of Biochemistry, Molecular Biology, Entomology and Plant Pathology, Mississippi State University, Mississippi State, MS 39762, USA. ${ }^{3}$ Department of Pathobiology and Population Medicine, Mississippi State University, Mississippi State, MS 39762, USA.

Received: 20 March 2017 Accepted: 10 January 2018 Published online: 18 January 2018

\section{References}

1. Rodríguez-Martínez H, Kvist U, Ernerudh J, Sanz L, Calvete JJ. Seminal plasma proteins: what role do they play? Am J Reprod Immunol. 2011;66:11-22.

2. López Rodríguez A, Rijsselaere T, Beek J, Vyt P, Van Soom A, Maes D. Boar seminal plasma components and their relation with semen quality. Syst Biol Reprod Med. 2013;0(0):1-8.

3. Feugang JM, Pendarvis K, Crenshaw M, Willard ST, Ryan PL. Highthroughput proteomic assessment of frozen-thawed boar spermatozoa. Reprod Fertil Dev. 2010;23(1):194.

4. Peddinti D, Nanduri B, Kaya A, Feugang JM, Burgess SC, Memili E. Comprehensive proteomic analysis of bovine spermatozoa of varying fertility rates and identification of biomarkers associated with fertility. BMC Syst Biol. 2008:2:19.

5. Verstegen J, Iguer-Ouada M, Onclin K. Computer assisted semen analyzers in andrology research and veterinary practice. Theriogenology. 2002;57(1):149-79.

6. Amann RP, Waberski D. Computer-assisted sperm analysis (CASA): capabilities and potential developments. Theriogenology. 2014;81(1):5-17.e13.

7. Didion BA. Computer-assisted semen analysis and its utility for profiling boar semen samples. Theriogenology. 2008;70(8):1374-6.

8. Niżański W, Partyka A, Prochowska S. Evaluation of spermatozoal function—useful tools or just science. Reprod Domest Anim. 2015;51:37-45.

9. Sutovsky P. New approaches to boar semen evaluation, processing and improvement. Reprod Domest Anim. 2015;50:11-9.

10. Druart X, Rickard JP, Mactier S, Kohnke PL, Kershaw-Young CM, Bathgate R, Gibb Z, Crossett B, Tsikis G, Labas V, et al. Proteomic characterization and cross species comparison of mammalian seminal plasma. J Proteome. 2013; 91(0):13-22.

11. Caballero I, Vazquez J, Garcia E, Parrilla I, Roca J, Calvete J, Sanz L, Martinez E. Major proteins of boar seminal plasma as a tool for biotechnological preservation of spermatozoa. Theriogenology. 2008;70(8):1352-5.

12. Caballero I, Parrilla I, Almiñana C, del Olmo D, Roca J, Martínez EA, Vázquez $J M$. Seminal plasma proteins as modulators of the sperm function and their application in sperm biotechnologies. Reprod Domest Anim. 2012;47:12-21.

13. Leahy T, Gadella BM. Sperm surface changes and physiological consequences induced by sperm handling and storage. Reproduction. 2011; 142(6):759-78.

14. Dacheux J-L, Gatti JL, Dacheux F. Contribution of epididymal secretory proteins for spermatozoa maturation. Microsc Res Tech. 2003;61(1):7-17.

15. Sharma R, Agarwal A, Mohanty G, Hamada AJ, Gopalan B, Willard B, Yadav S, Du Plessis S. Proteomic analysis of human spermatozoa proteins with oxidative stress. Reprod Biol Endocrinol. 2013;11(1):48.

16. Soggiu A, Piras C, Hussein HA, De Canio M, Gaviraghi A, Galli A, Urbani A, Bonizzi L, Roncada P. Unravelling the bull fertility proteome. Mol BioSyst. 2013;9(6):1188-95

17. De Canio M, Soggiu A, Piras C, Bonizzi L, Galli A, Urbani A, Roncada P. Differential protein profile in sexed bovine semen: shotgun proteomics investigation. Mol BioSyst. 2014;10(6):1264-71.

18. Feugang JM, Rozanas C, Kaya A, Topper E, Memili E. Proteome of bull spermatozoa. Reprod Fertil Dev. 2008;20(1):130.

19. D'Amours O, Frenette G, Fortier MN, Leclerc P, Sullivan R. Proteomic comparison of detergent-extracted sperm proteins from bulls with different fertility indexes. Reproduction. 2010;139(3):545-56.

20. Baker MA, Hetherington L, Reeves G, Müller J, Aitken RJ. The rat sperm proteome characterized via IPG strip prefractionation and LC-MS/MS identification. Proteomics. 2008;8(11):2312-21. 
21. Baker MA, Hetherington $L$, Reeves $G M$, Aitken RJ. The mouse sperm proteome characterized via IPG strip prefractionation and LC-MS/MS identification. Proteomics. 2008;8(8):1720-30.

22. Johnston DS, Wooters JOE, Kopf GS, Qiu Y, Roberts KP. Analysis of the human sperm proteome. Annals of the New ork Academy of Sciences. 2005;1061(1):190-202.

23. Chu DS, Liu H, Nix P, Wu TF, Ralston EJ, Yates lii JR, Meyer BJ. Sperm chromatin proteomics identifies evolutionarily conserved fertility factors. Nature. 2006:443(7107):101-5.

24. Oliva R, De Mateo S, Castillo J, Azpiazu R, Oriola J, Ballescà JL. Methodological advances in sperm proteomics. Hum Fertil. 2010;13(4):263-7.

25. Baker MA, Aitken RJ. Proteomic insights into spermatozoa: critiques, comments and concerns. Expert review of proteomics. 2009;6(6):691-705.

26. Baker MA. The 'omics revolution and our understanding of sperm cell biology. Asian j androl. 2011;13(1):6-10.

27. Zhang Y, Fonslow BR, Shan B, Baek M-C, Yates JR III. Protein analysis by shotgun/bottom-up proteomics. Chem Rev. 2013;113(4):2343-94.

28. Marouga R, David S, Hawkins E. The development of the DIGE system: 2D fluorescence difference gel analysis technology. Anal Bioanal Chem. 2005; 382(3):669-78

29. Westermeier R, Naven T. Expression proteomics. Proteomics in Practice: A Laboratory Manual of Proteome Analysis. 2002;16(5):11-160.

30. Holland A, Ohlendieck K. Comparative profiling of the sperm proteome. Proteomics. 2015;15(4):632-48.

31. Byrne K, Leahy T, McCulloch R, Colgrave ML, Holland MK. Comprehensive mapping of the bull sperm surface proteome. Proteomics. 2012;12(23-24): 3559-79.

32. Vilagran I, Yeste M, Sancho S, Castillo J, Oliva R, Bonet S. Comparative analysis of boar seminal plasma proteome from different freezability ejaculates and identification of Fibronectin 1 as sperm freezability marker. Andrology. 2015;3(2):345-56.

33. Kwon WS, Rahman MS, Lee JS, Kim J, Yoon SJ, Park YJ, You YA, Hwang S, Pang MG. A comprehensive proteomic approach to identifying capacitation related proteins in boar spermatozoa. BMC Genomics. 2014;15:897.

34. Chen X, Zhu H, Hu C, Hao H, Zhang J, Li K, Zhao X, Qin T, Zhao K, Zhu H, et al. Identification of differentially expressed proteins in fresh and frozenthawed boar spermatozoa by iTRAQ-coupled 2D LC-MS/MS. Reproduction. 2014;147(3):321-30.

35. González-Cadavid V, Martins JA, Moreno FB, Andrade TS, Santos AC, Monteiro-Moreira ACO, Moreira RA, Moura AA. Seminal plasma proteins of adult boars and correlations with sperm parameters. Theriogenology. 2014; 82(5):697-707.

36. Perez-Patiño C, Barranco I, Parrilla I, Valero ML, Martinez EA, Rodriguez-Martinez $\mathrm{H}$, Roca J. Characterization of the porcine seminal plasma proteome comparing ejaculate portions. J Proteome. 2016;142(Supplement C):15-23.

37. Feugang JM, Rodriguez-Munoz JC, Willard ST, Bathgate RA, Ryan PL. Examination of relaxin and its receptors expression in pig gametes and embryos. Reprod Biol Endocrinol. 2011;9:10.

38. Feugang JM, Greene JM, Sanchez-Rodriguez HL, Stokes JV, Crenshaw MA, Willard ST, Ryan PL. Profiling of relaxin and its receptor proteins in boar reproductive tissues and spermatozoa. Reprod Biol Endocrinol. 2015;13(1):46.

39. Zhang J, Ma J, Dou L, Wu S, Qian X, Xie H, Zhu Y, He F. Mass measurement errors of Fourier-transform mass spectrometry (FTMS): distribution, recalibration, and application. J Proteome Res. 2009;8(2):849-59.

40. Yates JR 3rd, Eng JK, McCormack AL, Schieltz D. Method to correlate tandem mass spectra of modified peptides to amino acid sequences in the protein database. Anal Chem. 1995;67(8):1426-36.

41. McCarthy FM, Wang N, Magee GB, Nanduri B, Lawrence ML, Camon EB, Barrell DG, Hill DP, Dolan ME, Williams WP. AgBase: a functional genomics resource for agriculture. BMC Genomics. 2006;7(1):1.

42. Huang DW, Sherman BT, Lempicki RA. Systematic and integrative analysis of large gene lists using DAVID bioinformatics resources. Nat Protoc. 2009;4(1): 44-57.

43. Feugang JM, Youngblood RC, Greene JM, Willard ST, Ryan PL. Selfilluminating quantum dots for non-invasive bioluminescence imaging of mammalian gametes. J Nanobiotechnology. 2015;13(1):38.

44. Pendarvis K, Kumar R, Burgess SC, Nanduri B. An automated proteomic data analysis workflow for mass spectrometry. BMC Bioinformatics. 2009;10(Suppl 11):S17.

45. Lundgren DH, Hwang S-I, Wu L, Han DK. Role of spectral counting in quantitative proteomics. Expert review of proteomics. 2010;7(1):39-53.
46. Gilany K, Lakpour N, Vafakhah M, Sadeghi MR. The profile of human sperm proteome; a mini-review. Journal of reproduction \& infertility. 2011;12(3):193-9.

47. Vilagran I, Castillo J, Bonet S, Sancho S, Yeste M, Estanyol JM, Oliva R. Acrosin-binding protein (ACRBP) and triosephosphate isomerase (TPI) are good markers to predict boar sperm freezing capacity. Theriogenology. 2013;80(5):443-50

48. Calvete JJ, Mann K, Schafer W, Raida M, Sanz L, Topfer-Petersen E. Boar spermadhesin PSP-\|l: location of posttranslational modifications, heterodimer formation with PSP-I glycoforms and effect of dimerization on the ligandbinding capabilities of the subunits. FEBS Lett. 1995;365(2-3):179-82.

49. Yeste M. Recent advances in boar sperm cryopreservation: state of the art and current perspectives. Reprod Domest Anim. 2015;50:71-9.

50. Vilagran I, Castillo-Martín M, Prieto-Martínez N, Bonet S, Yeste M. Triosephosphate isomerase (TPI) and epididymal secretory glutathione peroxidase (GPX5) are markers for boar sperm quality. Anim Reprod Sci. 2016;165:22-30.

51. Prieto-Martínez N, Vilagran I, Morató R, Rodríguez-Gil JE, Yeste M, Bonet S Aquaporins 7 and 11 in boar spermatozoa: detection, localisation and relationship with sperm quality. Reprod Fertil Dev. 2016;28(6):663-72.

52. Song CY, Gao B, Wu H, Wang XY, Chen GH, Mao J. Spatial and temporal expression of spermadhesin genes in reproductive tracts of male and female pigs and ejaculated sperm. Theriogenology. 2010;73(5):551-9.

53. Prieto-Martínez N, Morató R, Vilagran I, Rodríguez-Gil JE, Bonet S, Yeste M. Aquaporins in boar spermatozoa. Part II: detection and localisation of aquaglyceroporin 3. Reprod Fertil Dev. 2015;18(1):1.

54. Suarez SS, Oliphant G. Interaction of rabbit spermatozoa and serum complement components. Biol Reprod. 1982;27(2):473-83.

55. Dostal J, Veselský L, Marounek M, Železná B, Jonakova V. Inhibition of bacterial and boar epididymal sperm immunogenicity by boar seminal immunosuppressive component in mice. J Reprod Fertil. 1997;111(1):135-41.

56. Töpfer-Petersen E, Ekhlasi-Hundrieser M, Kirchhoff C, Leeb T, Sieme H. The role of stallion seminal proteins in fertilisation. Anim Reprod Sci. 2005;89(1): 159-70.

57. Iwamoto T, Hiroaki H, Furuichi Y, Wada K, Satoh M, Satoh M, Osada T, Gagnon C. Cloning of boar SPMI gene which is expressed specifically in seminal vesicle and codes for a sperm motility inhibitor protein. FEBS Lett. 1995;368(3):420-4

58. Manaskova P, Jonakova V. Localization of porcine seminal plasma (PSP) proteins in the boar reproductive tract and spermatozoa. J Reprod Immunol. 2008;78(1):40-8.

59. Ekhlasi-Hundrieser M, Gohr K, Wagner A, Tsolova M, Petrunkina A, TöpferPetersen E. Spermadhesin AQN1 is a candidate receptor molecule involved in the formation of the oviductal sperm reservoir in the pig. Biol Reprod. 2005;73(3):536-45.

60. van Gestel RA, Brewis IA, Ashton PR, Brouwers JF, Gadella BM. Multiple proteins present in purified porcine sperm apical plasma membranes interact with the zona pellucida of the oocyte. Mol Hum Reprod. 2007;13(7): 445-54

61. Castellani-Ceresa L, Berruti G, Colombo R. Immunocytochemical localization of acrosin in boar spermatozoa. J Exp Zool. 1983;227(2):297-304.

62. Barros C, Melendez J, Valdivia M, Rios M, Yunes R. Sperm passage through the egg coats. Biol Res. 1993;26:417.

63. Töpfer-Petersen E. Molecular mechanism of fertilization in the pig. Reprod Domest Anim. 1995;31(1):93-100.

64. Nascimento JM, Shi LZ, Chandsawangbhuwana C, Tam J, Durrant B, Botvinick EL, Berns MW: Use of laser tweezers to analyze sperm motility and mitochondrial membrane potential. J Biomed Opt 2008, 13(1):014002.

65. Ford W. Glycolysis and sperm motility: does a spoonful of sugar help the flagellum go round? Hum Reprod Update. 2006;12(3):269-74.

66. Ruiz-Pesini E, Díez-Sánchez C, López-Pérez MJ, Enriquez JA. The role of the mitochondrion in sperm function: is there a place for oxidative phosphorylation or is this a purely glycolytic process? Curr Top Dev Biol. 2007;77:3-19.

67. Mukai C, Okuno M. Glycolysis plays a major role for adenosine triphosphate supplementation in mouse sperm flagellar movement. Biol Reprod. 2004; 71(2):540-7.

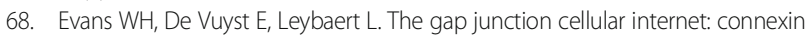
hemichannels enter the signalling limelight. Biochem J. 2006;397(1):1-14.

69. Giepmans BNG, Verlaan I, Hengeveld T, Janssen H, Calafat J, Falk MM, Moolenaar WH. Gap junction protein connexin-43 interacts directly with microtubules. Curr Biol. 2001;11(17):1364-8. 
70. Pinart $\mathrm{E}$, Yeste $\mathrm{M}$, Bonet $\mathrm{S}$. Acrosin activity is a good predictor of boar sperm freezability. Theriogenology. 2015;83(9):1525-33.

71. Moretti E, Terzuoli G, Mazzi L, lacoponi F, Collodel G. Immunolocalization of aquaporin 7 in human sperm and its relationship with semen parameters. Syst Biol Reprod Med. 2012;58(3):129-35.

72. Chen Q, Peng H, Lei L, Zhang Y, Kuang H, Cao Y, Shi Q-X, Ma T, Duan E. Aquaporin3 is a sperm water channel essential for postcopulatory sperm osmoadaptation and migration. Cell Res. 2011;21(6):922-33.

73. Sales AD, Lobo CH, Carvalho AA, Moura AA, Rodrigues AP. Structure, function, and localization of aquaporins: their possible implications on gamete cryopreservation. Genet Mol Res. 2013;12(4):6718-32.

Submit your next manuscript to BioMed Central and we will help you at every step:

- We accept pre-submission inquiries

- Our selector tool helps you to find the most relevant journal

- We provide round the clock customer support

- Convenient online submission

- Thorough peer review

- Inclusion in PubMed and all major indexing services

- Maximum visibility for your research

Submit your manuscript at www.biomedcentral.com/submit
Biomed Central 